\title{
A Comparison of Drill and Broadcast Methods for Establishing Cover Crops on Beds
}

\author{
Eric B. Brennan ${ }^{1}$ and Jim E. Leap \\ U.S. Department of Agriculture, Agricultural Research Service, U.S. \\ Agricultural Research Station, 1636 E. Alisal Street, Salinas, CA 93905
}

Additional index words. organic farming, planting method, rye, seedling establishment, vegetable production, vetch

\begin{abstract}
Cover crop stands that are sufficiently dense soon after planting are more likely to suppress weeds, scavenge nutrients, and reduce erosion. Small-scale organic vegetable farmers often broadcast cover crop seed to establish cover crops but lack information on the most effective implements to incorporate the seed into the soil. Experiments were conducted with winter- and spring-sown cover crops to compare drilling vs. broadcasting methods for establishing rye (Secale cereale L.) mixed with either purple (Vicia benghalensis $L$., winter) or common vetch ( $V$. sativa $L$., spring) on bed tops at a seeding rate of $140 \mathrm{~kg} \cdot \mathrm{ha}^{-1}$ in Salinas, CA. Broadcast seed was incorporated with a rototiller, cultivator, or tandem disc. Cover crop stand uniformity was assessed visually, and cover crop emergence over time and seeding depth were measured. Stands were more uniform after drilling or broadcast + rototiller incorporation compared with the other methods. Cover crops emerged sooner and in higher densities after drilling compared with broadcasting. The delayed emergence of broadcast seed was most apparent during the cooler winter experiment, particularly with purple vetch. Most drilled seed emerged from 2-cm depth compared with the broadcast seed that emerged from up to 11-cm depth with the greatest variability after disc or rototiller incorporation. The data indicate that the cultivator and rototiller are preferable implements to incorporate broadcast seed on beds, but that $50 \%$ to $100 \%$ higher seeding rates for broadcasting than drilling are needed. The practical implications for weed and soil management, and planting costs are discussed.
\end{abstract}

Establishing a uniform and sufficiently dense cover crop stand as soon as possible after planting is a critical first step to enable the cover crop to provide desirable services such as weed suppression, nitrate scavenging, and erosion control. Weed management is challenging in organic systems, and it is well known that narrow rows and dense and spatially uniform crop stands are more competitive with weeds (Brennan et al., 2009; Mohler, 2000; Olsen et al., 2005, 2012; Weiner et al., 2001). Suppressing weeds that grow during winter cover cropping is particularly important in tillage-intensive, high-value vegetable and strawberry production regions such as the central coast of California where many annual weed species grow year-round and can add large amounts of seed to the weed seedbank (Boyd and Brennan, 2006; Brennan and Smith, 2005). Many vegetable crops require

Received for publication 21 Nov. 2013. Accepted for publication 7 Feb. 2014.

We thank Darryl Wong and Damian Parr for reviews of an earlier version of this manuscript.

The U.S. Department of Agriculture (USDA) is an equal opportunity provider and employer. Mention of trade names or commercial products in this publication is solely for the purpose of providing specific information and does not imply recommendation or endorsement by the USDA.

${ }^{1}$ To whom reprint requests should be addressed; e-mail eric.brennan@ars.usda.gov. hand-weeding, which can be cost-prohibitive if weed seedbanks are not carefully managed. Shade reduces seed production of many weed species (Benvenuti et al., 1994; Chauhan, 2013; McLachlan et al., 1995; Steinmaus and Norris, 2002); therefore, planting strategies that hasten cover crop emergence and reduce light penetration to understory weeds should be a primary focus of cover cropping.

Drilling and broadcasting are the two methods to plant cover crops (Fisher et al., 2011; Van Horn et al., 2011). In vegetable and strawberry systems in the central coast region of California, grain drills are commonly used by medium- (i.e., $\approx 100$ ha) to large-scale (greater than 200 ha) farms, whereas smaller-scale organic farms with fewer resources often broadcast cover crop seed onto the soil surface and incorporate it into the soil in a separate pass with a secondary tillage implement. Although numerous studies have compared broadcast vs. drilling of agronomic crops (Ball, 1986; Collins and Fowler, 1992; Heege, 1993; Kiesselbach and Lyness, 1934; Oxner et al., 1997; Popp et al., 2000), pastures or forage crops (Bartholomew et al., 2011; Bellotti and Blair, 1989c; Edwards, 1998), and grassland restoration (Larson et al., 2011; Yurkonis et al., 2010), relatively few such comparisons have been done with cover crops (Fisher et al., 2011; Jeon et al., 2011; Kaspar et al., 2012). The effects of these contrasting sowing techniques on crop performance vary depending on a variety of factors (i.e., seeding rate, soil and seedbed condition, crop, sowing implement, method, climate, post-seeding tillage, etc.) and the primary objective of growing the crop (i.e., grain, forage, weed suppression, pasture renovation, etc.), making it difficult to conclude that one method is universally preferable. Part of the challenge of making such a generalization stems from the diversity of implements that are used to broadcast the seed (i.e., centrifugal spreaders that fling seed horizontally across the soil vs. implements attached to tractors or aircraft that drop the seed vertically onto the soil) and whether and how the seed is incorporated into the soil.

Ball (1986) noted that broadcasting is "an attractive technique for growing cereals cheaply by reducing fuel, machinery and labor in a wide range of soil conditions"; however, the dominance of drilling in mechanized agriculture for more than a century (Heege, 1993) suggests that farmers prefer drilling. This preference is likely because of the poor stands that can result from broadcasting as a result of a variety of commonly cited broadcasting challenges such as variability in seed distribution and seeding depth, soil-seed contact, and predation of seed on the soil surface. These challenges explain why extension publications typically recommend $20 \%$ to $50 \%$ higher seeding rates when broadcasting than drilling (Jeffers and Beuerlein, 2001; Kearney et al., 2006).

To our knowledge, previous studies have not compared broadcasting vs. drilling methods for bedded production systems where high-value vegetables are rotated with cover crops. To address this information gap, we conducted a study that evaluated the effectiveness of three secondary tillage implements for soil incorporation of broadcast cover crop seed compared with drilled seed using legume-rye cover crop mixtures. Our study was motivated by the need for effective strategies that will enable small-scale growers without access to a drill to grow uniform and weed-suppressive cover crops on beds. In our comparison of four planting methods, we evaluated stand density at various times, seed depth, and visually assessed overall stand uniformity. The implements evaluated represent those typically used in organic and conventional vegetable row cropping systems in California and were configured for a $2.03-\mathrm{m}$ wide bed system, which is a standard bed configuration here.

\section{Materials and Methods}

Two field experiments were conducted in a 0.24-ha field at the USDA-ARS organic research farm in Salinas, CA. The soil is a Chualar loamy sand (fine-loamy, mixed, superactive, thermic Typic Argixerol). The field had been cover-cropped for several years before the study. Field preparation included disc harrowing and ring rolling (i.e., cultipacking) as needed to incorporate previous cover crop residue and break up large clods. A global positioning system-guided tractor with lister 
shovels was used to create slightly peaked beds that were $2.03 \mathrm{~m}$ wide and $20 \mathrm{~m}$ long. Using a bed cultivator (Perfecta ${ }^{\circledR}$ II bedded crop field cultivator; Unverferth Mfg., Kalida, $\mathrm{OH}$ ), the beds were then shaped to create uniform and level bed tops that were $\approx 1.5 \mathrm{~m}$ wide and $15 \mathrm{~cm}$ above the furrow bottoms. Bed shaping and planting operations were performed with a tractor (Model 5525; John Deere, Moline, IL) with wheel spacing at $2.03 \mathrm{~m}$ that ran in the furrow bottoms between the beds. These bed preparation procedures were typical of those used to prepare beds for vegetable seeding in this region.

The experimental design was a randomized complete block with five blocks of the four planting treatments for both experiments. The experimental unit was a set of three adjacent beds with the center bed used for data collection. The four treatments included a drilled treatment (drill) and three treatments where broadcast seed was incorporated with a power takeoff-driven rototiller (broadcast + rototiller), a bed cultivator (broadcast + cultivator), or a disc harrow (broadcast + disc). Implement settings and details are in Table 1 . The cover crops were mixtures of $50 \%$ cereal rye (Secale cereale L., 'AGS 104') and 50\% purple vetch (Vicia benghalensis L.) for Expt. 1 and 50\% rye and $50 \%$ common vetch ( $V$. sativa L.) for Expt. 2. Mixture percentages were by seed weight and seed was from L.A. Hearne Seed Company (King City, CA).

A Sutton Seeder (Sutton Agricultural Enterprises Inc., Salinas, CA) was calibrated

Table 1. Three point implements and settings of four treatments for planting cover crops on beds in Expts. 1 and 2.

\begin{tabular}{|c|c|c|}
\hline Treatment & Implements $^{2}$ & Implement settings \\
\hline$\overline{\text { Drill }}$ & Sutton Seeder & $\begin{array}{l}\text { Seeder shoes set to drill seed at } 1.9-\mathrm{cm} \text { soil } \\
\text { depth; tractor speed } 5.15 \mathrm{~km} \cdot \mathrm{h}^{-1} \text {; seeder } \\
\text { agitator speed } 32 \mathrm{rpm} \text {; seed plate } \# 22 .\end{array}$ \\
\hline Broadcast + rototiller & Sutton Seeder ${ }^{y}+$ rototiller $^{x}$ & $\begin{array}{l}\text { Tiller blades set at a soil depth of } \approx 10 \mathrm{~cm} \\
\text { below the bed top; tractor speed } 2.6 \mathrm{~km} \cdot \mathrm{h}^{-1} \text {; } \\
\text { tractor engine speed } 2000 \mathrm{rpm} .\end{array}$ \\
\hline Broadcast + cultivator & Sutton Seeder ${ }^{\mathrm{y}}+$ cultivator $^{\mathrm{w}}$ & $\begin{array}{l}\text { Adjusted to minimize soil dragging by spike } \\
\text { tooth gang; rolling basket adjusted to } \\
\text { the aggressive setting; tractor speed } \\
4.8 \mathrm{~km} \cdot \mathrm{h}^{-1} ; \mathrm{S} \text { tines and spike teeth adjusted } \\
\text { to a soil depth of } \approx 16 \mathrm{~cm} \text { below the bed top. }\end{array}$ \\
\hline Broadcast + disc & Sutton Seeder ${ }^{y}+\operatorname{disc}^{v}$ & $\begin{array}{l}\text { Disc blade depth set at a soil depth of } \approx 12 \mathrm{~cm} \\
\text { below the bed top, with the front disc gangs at } \\
\text { the second most aggressive setting }\left(14^{\circ}\right) \text { and } \\
\text { rear disc gangs at the least aggressive setting } \\
\left(7^{\circ}\right) \text {; tractor speed } 6.3 \mathrm{~km} \cdot \mathrm{h}^{-1} \text {; center sweep } \\
\text { between disc gangs set to the depth bottom of } \\
\text { disc blades; furrow disc hillers ( } 61 \text {-cm } \\
\text { diameter blades) set to maintain furrows. }\end{array}$ \\
\hline
\end{tabular}

${ }^{\mathrm{z}}$ All implements were connected to the three-point attachment of a tractor (Model 5525; John Deere, Moline, IL) with 2.03-m spacing between wheels.

${ }^{y}$ For the broadcast treatments, the Sutton Seeder broadcast seed $\approx 15 \mathrm{~cm}$ above the bed surface at the same tractor speed, agitator speed, and seed plate size as for the Drill treatment.

${ }^{x}$ John Deere (Model 680).

"Perfecta ${ }^{\circledR}$ II (Kalida, OH) "bedded crop field cultivator," also commonly known as a bed harrow. Included three gangs of S tines, a spike tooth leveling bar, rolling basket, and shovels that maintain the furrows.

${ }^{v}$ Land Pride (Salina, KS) tandem disc (Model DH25) with 56-cm diameter notched discs. The disc was modified as follows for use on beds. A single $33-\mathrm{cm}$ wide sweep was added in the center of the unit between the front and rear disc gangs to cultivate the center area missed by the discs. A bar was added behind the rear gang to position a disc hiller in each furrow to maintain the furrows. A flat $61-\mathrm{cm}$ diameter coulter was also mounted on the rear bar and ran at $\approx 20$-cm depth in the bed center to reduce sideward movement of the implement. way across the sampled bed top to avoid the edges and middle of the bed.

Expt. 2. The cover crop was planted on 19 May 2011 and sprinkler-irrigated as needed to germinate the seed. Cover crop emergence was determined as in Expt. 1 at 12 and 19 DAP. Like in previous studies (Olsen et al., 2012), photographs were used as a simple and effective way to characterize differences in crop spatial patterns and densities. Vetch seed depth was determined at 21 DAP by carefully hand-digging the seedlings in one $50 \times 50$-cm quadrat from each treatment plot. The seed depth of each uprooted seedling was determined to the nearest $\mathrm{mm}$ by measuring the length of the light-colored section of the epicotyl that had been below the soil surface. This technique was facilitated by the hypogeous germination characteristic of vetch whereby the cotyledons remain below ground at the depth where the seed germinated.

Statistical analysis. Separate analyses were conducted for each experiment using the MIXED procedure in SAS Version 9.3 (SAS Inst., Cary, NC). Within each experiment, a separate analysis was conducted for the two dates that cover crop emergence was measured. In the analyses, planting method was considered a fixed effect, and block was considered a random effect. Data were checked to meet the assumptions of analysis of variance and were transformed as needed, although back transformed means and $95 \%$ confidence intervals (CIs) are presented. Reciprocal transformations were used for total cover crop density and rye density at 12 and 19 DAP in Expt. 2. Multiple comparisons between the treatments were controlled at a familywise error rate of $P \leq 0.05$ using Tukey-Kramer adjustments. The MEANS procedure was used to calculate $95 \%$ CI of the response variables to help the reader make practical inferences about the data. Comparisons between treatment means with 95\% CI can be made using the "rule of eye" method whereby intervals that overlap with a mean are not different, and intervals that overlap by half of one interval arm are significantly different at $P \approx 0.05$ (Cumming, 2009); however, such comparisons are not adjusted to control the familywise error rate and this method is more robust when samples sizes are 10 or more. In several figures we included the data points of each replicate in addition to the mean and CI to illustrate the distribution of the data as suggested by Drummond and Vowler (2011).

\section{Results and Discussion}

Climate. During Expt. 1, the daily average air temperature ranged from 5 to $14{ }^{\circ} \mathrm{C}$ with an average of $10^{\circ} \mathrm{C}$, and cumulative rainfall was $121 \mathrm{~mm}$; rainfall distribution was 4 to $5 \mathrm{~mm}$ weekly during the first 2 weeks and 28 to $50 \mathrm{~mm}$ weekly for Weeks 3 to 5 . There was no precipitation during Expt. 2, and daily average air temperature ranged from 12 to $15{ }^{\circ} \mathrm{C}$ with an average of $13{ }^{\circ} \mathrm{C}$. A total of $19 \mathrm{~mm}$ of sprinkler irrigation was applied in a single irrigation event on the first day of 
Expt. 2. The rainfall distribution during Expt. 1 and irrigation application during Expt. 2 were ideal for cover crop germination.

Distribution of cover crop seedlings on bed tops and furrows. The four planting methods resulted in cover crop stands with visually distinctive patterns on the bed tops and furrows that were consistent across replications and experiments (Fig. 1). The drill and broadcast + rototiller methods provided the most spatially uniform distribution of cover crop plants across the bed tops and seldom had cover crop emergence in the furrows. In contrast, incorporating the broadcast seed with the cultivator or disc tended to concentrate the cover crop seed into two to three strips on either side of the bed top center. These strips were caused by the $\mathrm{S}$ tines on the cultivator and the tandem disc blades. Concentrating crop plants into such dense clusters is undesirable because it hastens intracrop competition and delays

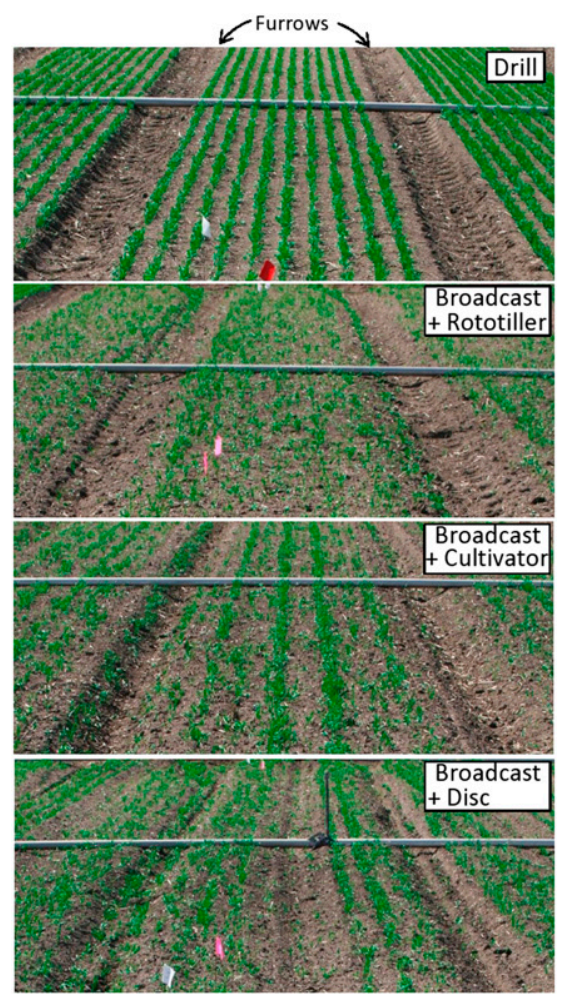

Fig. 1. Photographs of $203-\mathrm{cm}$ wide beds with a common vetch-rye cover crop mixture in Expt. 2, $13 \mathrm{~d}$ after planting with a drill, or broadcasting the seed on the soil surface and incorporated it with a rototiller, harrow, or disc. Planting occurred on 19 May 2011. Each photograph shows a centered bed of each treatment and a portion of the same treatment on the beds to the right and left. An irrigation pipe runs across the beds approximately onethird from the top of each photograph. At the resolution shown, the majority of green plants visible are cover crops rather than weeds; a few individual weeds are barely visible in the furrows of the of the drill and broadcast + rototiller treatments. The color of photographs was adjusted digitally to help visualize the cover crops relative to the soil. The pink, red, and white objects were plot flags. crop-weed competition (Fischer and Miles, 1973; Regnier and Bakelana, 1995). In future studies of this nature we encourage researchers to consider using Morisita's index of dispersion to provide a simple and robust measure of crop spatial uniformity and aggregation like in previous studies (Kristensen et al., 2006; Olsen et al., 2012) and provide insights into weed-suppressive potential of various sowing methods.

Incorporating seed with the cultivator and disc resulted in more cover crop emergence in the furrows than was observed in the other treatments. Cover crop emergence in the furrows can create management challenges at season end when the cover crop is terminated by mowing and incorporation because it can be more difficult to kill and incorporate cover crops in the furrows than bed tops. Ideally, shallow tillage can be used as needed to kill weeds that germinate in the furrows during the winter. In our region, cover cropping on beds is less common than cover cropping in unbedded fields; however, a bedded cover crop can minimize spring tillage if minimum tillage implements are used to incorporate the residue into the bed in preparation for the next vegetable crop (Fennimore and Jackson, 2003; Jackson et al., 1993). Furthermore, raised beds can improve winter drainage and help to aerate the crown and root system (Kearney et al., 2006).

Total cover crop density. Average total cover crop densities (rye + vetch) during the first 2 weeks after planting ranged from 151 to 302 plants $/ \mathrm{m}^{2}$ in Expt. 1 and from 224 to 359 plants $/ \mathrm{m}^{2}$ in Expt. 2 (Figs. 2A and 3A). These densities were within the typical range of legume-cereal cover crops in the region (Brennan et al., 2009; Brennan and Boyd, 2012a; Brennan and Smith, 2005). In both experiments, there were consistently greater total cover crop densities in the drill than broadcast treatments during the first 2 weeks

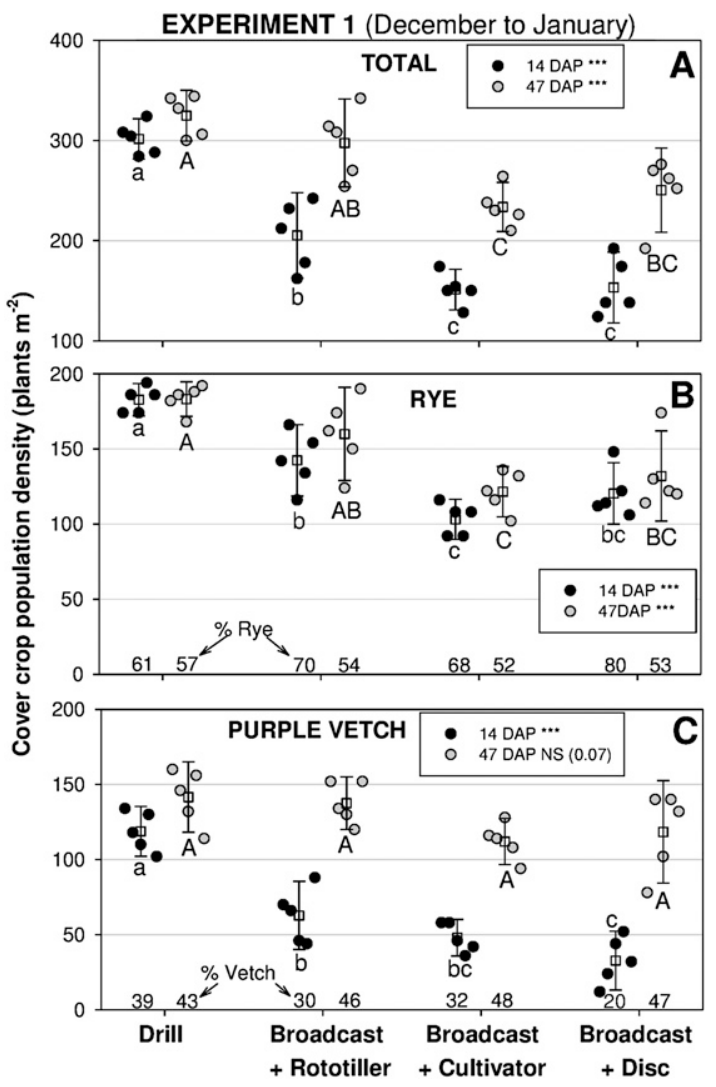

Fig. 2. Cover crop population densities at 14 and $47 \mathrm{~d}$ after planting (DAP) in a purple vetch-rye cover crop mixture that was drilled or broadcast and incorporated with a rototiller, a cultivator, or a disc. All treatments were planted at $140 \mathrm{~kg} \cdot \mathrm{ha}^{-1}$ on $2 \mathrm{Dec}$. 2010. The mixture included $50 \%$ of each seed type by seed weight. Each round black or gray dot in the cluster of five dots is the mean of two quadrats for each of the five replicates, and the open squares with error bars are the means $\pm 95 \%$ confidence intervals. The relative position of each dot with each cluster is offset (i.e., jittered) around the mean to avoid overlapping data points with the offset sequence in order from replicates 1 (left) to 5 (right). Means that are significantly different based on a Tukey-Kramer familywise error rate of $P \leq 0.05$ are indicated below each data cluster with different lower case letters for 14 DAP and different upper case letters for 47 DAP. ${ }^{* * *}$ There were significant treatment differences $(P \leq 0.001)$ at the two measurement times; NS = nonsignificant and the actual $P$ value is in parentheses. The percentage of rye and vetch plants is shown above the $\mathrm{x}$-axis for each cluster of data. Comparisons within planting treatment between the 14 and 47 DAP can be made using the "rule of eye" method whereby intervals that overlap with a mean are not different, and intervals that overlap by half of one interval arm are significantly different at $P \approx 0.05$ (Cumming, 2009). Note that the $y$-axis range of the total cover crop plot $(\mathbf{A})$ is greater than the range for the rye $(\mathbf{B})$ and vetch $(\mathbf{C})$ plots. 


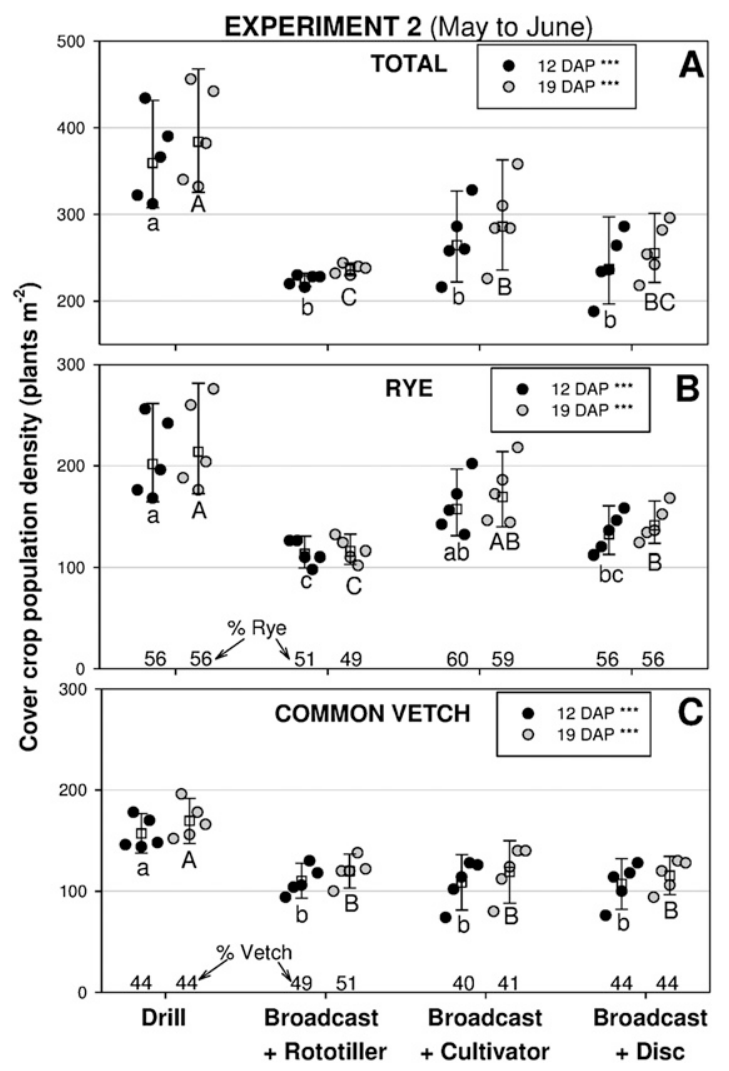

Fig. 3. Cover crop population densities at 12 and $19 \mathrm{~d}$ after planting (DAP) in a common vetch-rye cover crop mixture that was drilled or broadcast and incorporated with a rototiller, a cultivator, or a disc. All treatments were planted at $140 \mathrm{~kg} \cdot \mathrm{ha}^{-1}$ on 19 May 2011 . The mixture included $50 \%$ of each seed type by seed weight. Each round black or gray dot in the cluster of five dots is the mean of two quadrats for each of the five replicates, and the open squares with error bars are the means $\pm 95 \%$ confidence intervals. The relative position of each dot with each cluster is offset (i.e., jittered) around the mean to avoid overlapping data points with the offset sequence in order from replicates 1 (left) to 5 (right). Means that are significantly different based on a Tukey-Kramer familywise error rate of $P \leq 0.05$ are indicated below each data cluster with different lower case letters for 12 DAP and different upper case letters for 19 DAP. ***There were significant treatment differences $(P \leq 0.001)$ at the two measurement times. The percentage of rye and vetch plants is shown above the $\mathrm{x}$-axis for each cluster of data. Comparisons within planting treatment between the 12 and 19 DAP can be made using the "rule of eye" method whereby intervals that overlap with a mean are not different, and intervals that overlap by half of one interval arm are significantly different at $P \approx 0.05$ (Cumming, 2009). Note that the y-axis range of the total cover crop plot $(\mathbf{A})$ is greater than the range for the rye $(\mathbf{B})$ and vetch $(\mathbf{C})$ plots.

$(P \leq 0.001)$. For example, compared with the Drill treatment, there were $33 \%$ fewer seedlings in broadcast + rototiller and an average of $50 \%$ fewer in the broadcast + cultivator and broadcast + disc at 14 DAP in Expt. 1 (Fig. 2A). A similar pattern occurred in Expt. 2 where there were $26 \%$ to $38 \%$ fewer seedlings in the broadcast treatments than in the drill treatment at 12 DAP (Fig. 3A).

Within the broadcast treatments, broadcast + rototiller had an average of $53(35 \%)$ more total plants $/ \mathrm{m}^{2}$ than the other broadcast treatments at 14 DAP in Expt. 1; this general pattern continued to 47 DAP. In contrast, there were fewer differences in densities among broadcast treatments in Expt. 2; however, there was consistently less variability in the broadcast + rototiller treatment at both measurement dates (Fig. 3A).

In both experiments, the total densities increased from the first to second measurement date; however, the increase was most apparent in the broadcast treatments during Expt. 1. For example, between 14 and 47
DAP in Expt. 1, the average total density increased by 24 plants $/ \mathrm{m}^{2}(8 \%)$ in the Drill treatment compared with an average increase of 91 plants $/ \mathrm{m}^{2}(54 \%)$ in the broadcast treatments (Fig. 2A). In contrast, between 12 and 19 DAP in Expt. 2, the increase in total densities was only $7 \%\left(20\right.$ plants $\left./ \mathrm{m}^{2}\right)$ averaged across treatments (Fig. 3A). We attribute the greater change between measurement dates in total cover crop densities in Expt. 1 than Expt. 2 to the cooler temperatures during Expt. 1 that likely delayed emergence of deeper-placed seed in the broadcast treatments. Our results of delayed emergence of broadcast seed is consistent with previous studies with cover crops (Fisher et al., 2011) and perennial pasture grass (Bellotti and Blair, 1989b). It is important to note that the density differences between the broadcast + disc treatment relative to the other treatments would likely have been greater if we had collected data from across the entire bed top rather just one-third of the way across the bed.
Rye and vetch densities. Rye densities averaged across treatments were slightly lower during the first 2 weeks of experiment $1\left(137 \pm 15\right.$ plants $/ \mathrm{m}^{2}$, mean $\left.\pm 95 \% \mathrm{CI}\right)$ than Expt. $2(154 \pm 21)$ and changed relatively little thereafter (Figs. 2B and 3B). In general, broadcasting produced lower rye densities than the drilling; however, the relative ranking of the broadcast treatments varied between experiments; emergence was highest with rototiller incorporation in Expt. 1 vs. cultivator incorporation in Expt. 2.

Purple vetch densities were approximately two or more times greater in the Drill (119 plants $/ \mathrm{m}^{2}$ ) than broadcast treatments (33 to 63 plants $/ \mathrm{m}^{2}$ ) at 14 DAP in Expt. 1 (Fig. 2C) and these densities increased in all treatments, particularly in the broadcast treatments that more than doubled by 47 DAP. Purple vetch densities differed little between broadcast treatments. It is interesting to note that purple vetch emergence was slower than rye emergence, but over time, purple vetch densities in the broadcast treatments were comparable to the drill treatment, whereas this was generally not the case with rye. This indicates that rye was more sensitive than purple vetch to planting depth.

Broadcasting also reduced common vetch densities in Expt. 2 (Fig. 3C); however, the magnitude of the difference with the Drill treatment was not as great as with purple vetch in Expt. 1 (Fig. 2C). Furthermore, despite the slight increase in common vetch densities between 12 and 19 DAP, the densities in the broadcast treatments were an average of $31 \%$ lower $\left(52\right.$ fewer plants $/ \mathrm{m}^{2}$ ) than in the Drill treatment by 19 DAP.

Planting method had a clear effect on the proportion of the mixture components that emerged during Expt. 1, especially in the broadcast treatments. For example, the percentage of purple vetch increased in all treatments overtime; however, this change was relatively small in the Drill treatment (4\%) compared with the broadcast treatments where it ranged from $16 \%$ with rototiller and cultivator incorporation to $27 \%$ with disc incorporation. Research with mixtures in pasture and restoration plantings has similarly reported that the percentage of the mixture components that emerge and that make up the stand differ in broadcast vs. drill plantings (Bellotti and Blair, 1989a, 1989b, 1989c; Larson et al., 2011). Although legume seed accounts for $90 \%$ of the seed weight in typical legume-cereal mixtures in this region, cereal biomass often represents $70 \%$ to $90 \%$ of the total final cover crop biomass (Brennan et al., 2009, 2011; Brennan and Boyd, 2012b). Additional research is needed to determine if drilling vs. broadcasting planting method influences the legume's persistence in the mixture and its ability to produce desirable services such as nitrogen fixation. We speculate that broadcasting would reduce the amount of legume biomass produced if the incorporation method delays emergence of the legume component relative to the cereal as occurred in Expt. 1. 
Crop crop seed depth. There were marked differences in the seed depth of common vetch between planting methods (Fig. 4). As expected, drilling resulted in the most uniform seeding depth at $2 \mathrm{~cm}$. In contrast, all broadcast treatments had more variability in seed depth, particularly where the broadcast seed was incorporated with the rototiller or disc. Variability in seeding depth of various sowing methods is problematic because crop emergence decreases linearly with increased variability in seed depth (Heege, 1993). The differences in seed depth between planting methods help explain the lower densities and delayed emergence patterns in the broadcast treatments (Figs. 2 and 3). Our data indicate that of the three broadcast methods, the cultivator placed the broadcast seed at a relatively uniform depth that is most similar to drilling the seed. The shallower seed depth in the broadcast + cultivator plots compared with the other broadcast methods likely explains a trend toward greater rye emergence of the cultivator incorporated seed (Fig. 3B).

Practical implications. This study provides the first information on the effectiveness of drilling vs. broadcasting methods for planting cover crops on raised beds and illustrates the benefits of drilling over broadcasting. Our findings indicate that the tandem disc was the least suitable implement to incorporate broadcast seed into a raised bed because even with the disc adjusted to its least aggressive setting, it buried the seed deeper in the bed than is optimal, left a relatively deep groove with few cover crop plants in the bed center, and moved seed from the bed top into the furrow.

Our study indicates that either the rototiller or cultivator can be effective tools to incorporate broadcast seed in some situations. The rototiller has the potential to produce the most uniform stand of a broadcast cover crop; however, it would require approximately twice the incorporation time of the cultivator, more attention to control seed depth, and would also be less energy-efficient because it requires use of a tractor's power takeoff. The slower incorporation speed of the rototiller may also increase the chance of seed predation by birds, particularly if the same tractor is used to broadcast and incorporate, and there was more time elapsed from broadcasting to incorporation. Furthermore, the rototiller would be less suitable than the cultivator for small-seeded cover crops such as mustards that are less tolerant to deeper planting depths than cereals and grain legumes (Vicia spp.; pea, Pisum sativa L.) used as cover crops. Deeper seed placement by the rototiller would likely be more problematic in clay-textured soils that are known to inhibit emergence from deeper depths (Mutz and Scifres, 1975). However, the rototiller would have advantages over the

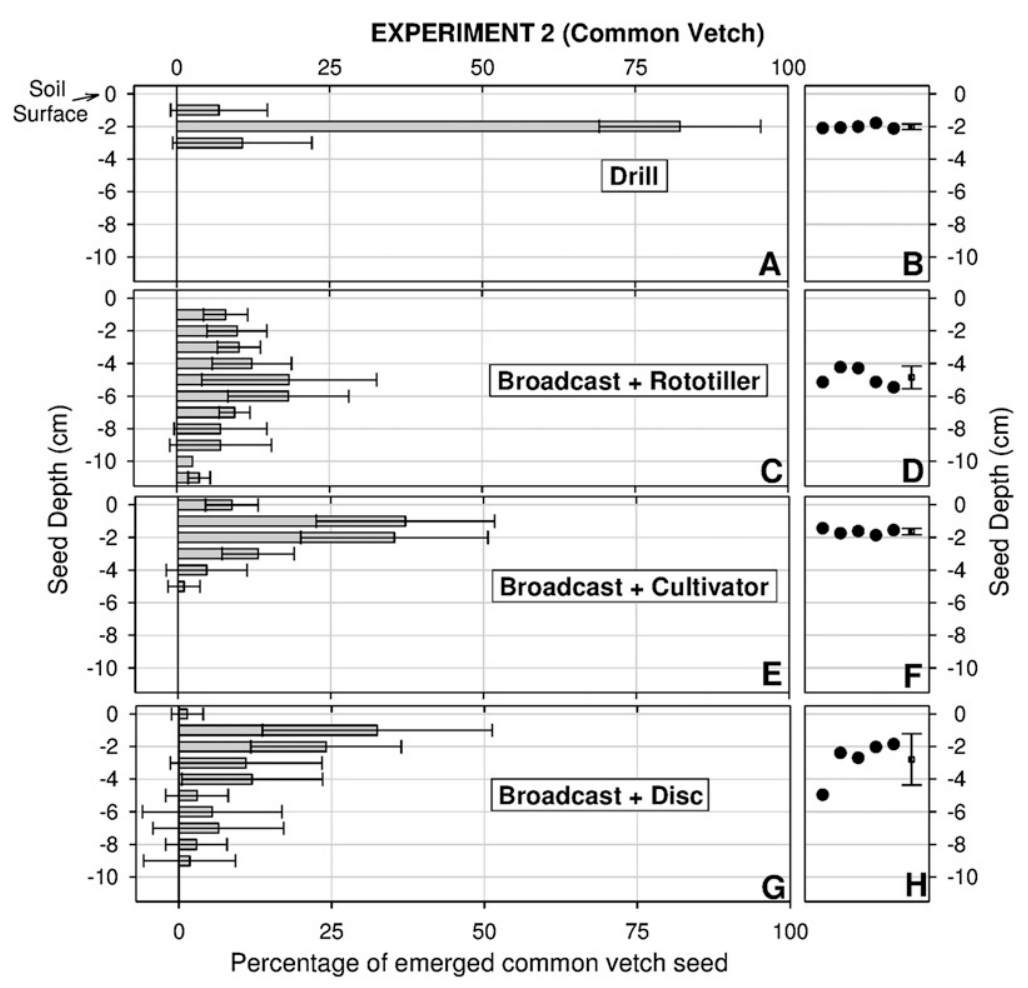

Fig. 4. The percentage of common vetch seedlings in Expt. 2 that emerged from various depths $(\mathbf{A}, \mathbf{C}, \mathbf{E}$ G) and average seed depth $(\mathbf{B}, \mathbf{D}, \mathbf{F}, \mathbf{H})$ with a drill or broadcast on the soil surface and incorporated with a rototiller, cultivator, or disc. The seeding rate was $140 \mathrm{~kg} \cdot \mathrm{ha}^{-1}$ for a common vetch-rye mixture that included $50 \%$ of each component by seed weight. Data were collected $21 \mathrm{~d}$ after planting (19 May 2011). Horizontal bars in plots $\mathbf{A}, \mathbf{C}, \mathbf{E}$, and $\mathbf{G}$ are mean $\pm 95 \%$ confidence interval. Plots $\mathbf{B}, \mathbf{D}, \mathbf{F}$, and $\mathbf{H}$ show the seed depth of each of the five replicates (round dots) and the mean $\pm 95 \%$ confidence interval. The total number of seedlings that provided the data summed across the five replicates was 165 (drill), 147 (broadcast + rototiller), 101 (broadcast + cultivator), and 104 (broadcast + disc). cultivator in beds with moderate amounts of previous crop residue because the rototiller's rotating tines would readily shred the residue. Additional research is needed to determine if simple modifications to the cultivator would reduce the strip pattern that it created. For example, we speculate that removing the $\mathrm{S}$ tines and relying only on the spike tooth gang and rolling basket may incorporate the seed more uniformly across the bed top. Furthermore, it would be useful to compare the effectiveness of other common cultivators that only have spike tooth tines and to evaluate these tools on a range of soil textures.

Although we did not measure weed suppression, it is likely that the drilled cover crops had the greatest potential to capture more light and thus suppress weeds because the drill produced denser and more spatially uniform stands sooner after planting than occurred with any of the broadcast methods. It is well known that deeper seed placement delays crop emergence (Tadmor and Cohen, 1968), which in turn delays competition between crops and weeds for light. Comparisons of drill and broadcast sowing methods have seldom evaluated light interception by the sown plants, but Yurkonis et al. (2010) showed greater interception in drilled stands. In California, canopy closure by fall-seeded cover crops within the first month after planting is a good general predictor of weed suppression (Brennan et al., 2009; Brennan and Smith, 2005). Our current study suggests that broadcast seeding rates should be 1.5 to two times higher than drilled rates to provide similar early-season densities. The rototiller and cultivator methods produced cover crop stands with opposite strengths and weakness in terms of planting depth and spatial uniformity that may influence weed suppression. For example, the more even distribution of cover crop plants on the bed top after the rototiller would likely enhance weed control relative to that after the cultivator; however, these benefits may not be realized if the rototiller delays cover crop emergence by burying the seed deeper below the soil surface.

Several issues need to be considered when deciding if the benefits of drilling cover crops would justify investing in a drill-type planter. Although broadcasting is usually considered a labor-saving approach to plant large areas quickly, this is clearly not the case with the broadcast systems we evaluated where the seed was broadcast and incorporated one bed at a time with separate broadcast and incorporation passes. Assuming the current hourly labor costs for a tractor operator in our region of $\approx \$ 20$ including benefits (Dara et al., 2012) and the travel speeds of the implements (Table 1), we estimate that compared with drilling, the time and hence labor costs of the broadcasting methods evaluated would be 1.9, 2.1, and 2.7 times higher for the disc, cultivator, and rototiller methods, respectively. These higher labor costs combined with the need for 1.5 to two times higher seeding rates for broadcast cover crops illustrate the potential savings that a drill can provide as the acreage in cover crop increases. 
The higher labor costs of the broadcast systems we evaluated were largely the result of the presence of beds that restricted us to use implements that retained the bed during soil incorporation of the seed. Although cover crops are grown on beds and unbedded fields in this region, cover cropping on beds can allow smaller areas to be cover-cropped regularly and can potentially save time and reduce fuel use if the cover-cropped beds are to be "recycled" into bedded vegetable crops using minimum tillage implements (Jackson et al., 2002).

An important issue to consider when growing cover crops on beds involves choosing an effective implement to either drill or broadcast the seed onto the bed top. Highdensity vegetable planters that are configured for wide beds such as we used in our experiments can work well for cover crops with small- (i.e., mustard) to medium- (i.e., small grains and vetch) sized seed; such planters typically cost U.S. $\approx \$ 9000$ for the basic model we used in our study. Standard pull or three-point-type grain drills can work well assuming that their planting width and drive wheel spacing fits well with the bed width; drive wheels that fit in the furrow between beds are preferable to avoid potential problems with drive wheel tracks on bed tops. Relatively inexpensive (i.e., U.S. \$1000) drop-type broadcast spreaders with variable rate settings that are typically used for lime and fertilizer application may also work for planting cover crops on bed tops but would require a second pass to incorporate the seed. A centrifugal broadcast seeder could also be used for planting cover crop on beds but would also place seed into the furrows.

It is unknown if the lower-density cover crop stands in the broadcast methods would compensate and produce the same final cover crop biomass as a drilled cover crop. Several previous studies from this region reported that final biomass production was typically unaffected by stand density differences caused by altering seeding rate (Boyd et al., 2009; Brennan et al., 2009; Brennan and Boyd, 2012a). However, in contrast to those previous studies in which lower densities were the result of lower seeding rates, the reduced densities in the broadcast + disc and broadcast + rototiller treatments in our present study were the result of slower emergence from deeper seeding depths. Seedlings that emerge from deeper depths often have reduced vigor and reduced biomass and root production, fewer tillers, and reduced hydraulic conductance (Arnott, 1969; Fulbright et al., 1985; Hadjichristodoulou et al., 1977; Kirby, 1993; Loeppky et al., 1989; Lueck et al., 1949; Mahdi et al., 1998; Mutz and Scifres, 1975; Photiades and Hadjichristodoulou, 1984; Redmann and Qi, 1992; Tischler and Voigt, 1983); all of these characteristics would likely reduce the crop's ability to capture limited resources (i.e., light, nutrients, and moisture) and hence to suppress weeds. Additional research is needed to determine if these potential problems with deeper planted seed have a negative effect on a broadcast cover crop's ability to provide important services such as weed suppression, nitrate scavenging, and cover crop biomass production. Despite the potential problems from deeper seed placement from broadcasting, several studies reported equivalent yields of drilled vs. broadcast stands of agronomic crops (Graham and Ellis, 1980; Popp et al., 2000).

In conclusion, our study shows the benefits of drilling vs. broadcasting methods for establishing uniform cover crops on beds. Drilling required less time than broadcasting because the broadcasting methods all used a second pass to incorporate the seed. The data suggest that at a given seeding rate, drilled cover crops had characteristics such as greater uniformity and faster emergence that would likely increase their ability to suppress weeds that emerge with the cover crop. The main problems with the broadcasting methods evaluated were delayed emergence and lower cover crop stands that were likely the result of greater variability in seeding depth. The best methods to incorporate broadcast seed into the bed were a rototiller or a cultivator with tines and a rolling basket, preferably at $50 \%$ to $100 \%$ higher seeding rates than drilling. Additional research is needed to determine if modifications to the cultivator would reduce its tendency to concentrate the seed in strips.

\section{Literature Cited}

Arnott, R.A. 1969. Effect of seed weight and depth of sowing on emergence and early seedling growth of perennial ryegrass (Lolium perenne). J. Br. Grassl. Soc. 24:104-110.

Ball, B.C. 1986. Cereal production with broadcast seed and reduced tillage-A review of recent experimental and farming experience. J. Agr. Eng. Res. 35:71-95.

Bartholomew, P.W., J.M. Schneider, and R.D. Williams. 2011. Pasture residue amount and sowing method effects on establishment of overseeded cool-season grasses and on total annual production of herbage. Grass Forage Sci. 66:560-568.

Bellotti, W.D. and G.J. Blair. 1989a. The influence of sowing method on perennial grass establishment. 1. Dry-matter yield and botanical composition. Aust. J. Agr. Res. 40:301-311.

Bellotti, W.D. and G.J. Blair. 1989b. The influence of sowing method on perennial grass establishment. 2. Seedbed microenvironment, germination and emergence. Aust. J. Agr. Res. 40:313321.

Bellotti, W.D. and G.J. Blair. 1989c. The influence of sowing method on perennial grass establishment. 3. Survival and growth of emerged seedlings. Aust. J. Agr. Res. 40:323-331.

Benvenuti, S., M. Macchia, and A. Stefani. 1994. Effects of shade on reproduction and some morphological-Characteristics of Abutilontheophrasti medicus, Datura-stramonium 1 and Sorghum-halepense L pers. Weed Res. 34:283-288.

Boyd, N.S. and E.B. Brennan. 2006. Weed management in a legume-cereal cover crop with the rotary hoe. Weed Technol. 20:733-737.

Boyd, N.S., E.B. Brennan, R.F. Smith, and R. Yokota. 2009. Effect of seeding rate and planting arrangement on rye cover crop and weed growth. Agron. J. 101:47-51.

Brennan, E.B. and N.S. Boyd. 2012a. Winter cover crop seeding rate and variety effects during eight years of organic vegetables: I. Cover crop biomass production. Agron. J. 104:684-698.

Brennan, E.B. and N.S. Boyd. 2012b. Winter cover crop seeding rate and variety effects during eight years of organic vegetables: II. Cover crop nitrogen accumulation. Agron. J. 104:799-806.

Brennan, E.B., N.S. Boyd, R.F. Smith, and P. Foster. 2009. Seeding rate and planting arrangement effects on growth and weed suppression of a legume-oat cover crop for organic vegetable systems. Agron. J. 101:979-988.

Brennan, E.B., N.S. Boyd, R.F. Smith, and P. Foster. 2011. Comparison of rye and legumerye cover crop mixtures for vegetable production in California. Agron. J. 103:449-463.

Brennan, E.B. and R.F. Smith. 2005. Winter cover crop growth and weed suppression on the central coast of California. Weed Technol. 19:10171024.

Chauhan, B.S. 2013. Shade reduces growth and seed production of Echinochloa colona, Echinochloa crus-galli, and Echinochloa glabrescens. Crop Prot. 43:241-245.

Collins, B.A. and D.B. Fowler. 1992. A comparison of broadcast and drill methods for no-till seeding winter-wheat. Can. J. Plant Sci. 72:10011008.

Cumming, G. 2009. Inference by eye: Reading the overlap of independent confidence intervals. Stat. Med. 28:205-220.

Dara, S.K., K.M. Klonsky, and K.P. Tumber. 2012. Sample costs to produce fresh market broccoli. University of California Cooperative Extension, Davis, CA.

Drummond, G.B. and S.L. Vowler. 2011. Show the data, don't conceal them. Clin. Exp. Pharmacol. Physiol. 38:287-289.

Edwards, L. 1998. Comparison of two spring seeding methods to establish forage cover crops in relay with winter cereals. Soil Tillage Res. $45: 227-235$

Fennimore, S.A. and L.E. Jackson. 2003. Organic amendment and tillage effects on vegetable field weed emergence and seedbanks. Weed Technol. 17:42-50.

Fischer, R.A. and R.E. Miles. 1973. The role of spatial pattern in the competition between crop plants and weeds. A theoretical analysis. Math. Biosci. 18:335-350.

Fisher, K.A., B. Momen, and R.J. Kratochvil. 2011. Is broadcasting seed an effective winter cover crop planting method? Agron. J. 103:472-478.

Fulbright, T.E., A.M. Wilson, and E.F. Redente. 1985. Green needlegrass seedling morphology in relation to planting depth. J. Range Mgt. 38:266-270.

Graham, J.P. and F.B. Ellis. 1980. The merits of precision drilling and broadcasting for the establishment of cereal crops in Britain. ADAS Quarterly Review. p. 160-169.

Hadjichristodoulou, A., A. Della, and J. Photiades. 1977. Effect of sowing depth on plant establishment, tillering capacity and other agronomic characters of cereals. J. Agr. Sci. 89:161-167.

Heege, H.J. 1993. Seeding methods performance for cereals, rape, and beans. Trans. ASAE 36:653-661.

Jackson, L.E., I.R. Ramirez, I. Morales, and S.T. Koike. 2002. Minimum tillage practices affect disease and yield of lettuce. Calif. Agr. 56:35-39.

Jackson, L.E., L.J. Wyland, and L.J. Stivers. 1993. Winter cover crops to minimize nitrate losses in intensive lettuce production. J. Agr. Sci. 121:55-62.

Jeffers, D.L. and J. Beuerlein. 2001. Arial and other broadcast methods of seeding wheat. Ohio State 
University Extension. 3 Mar. 2014. <http:// ohioline.osu.edu/agf-fact/pdf/0105.pdf $>$.

Jeon, W.T., B. Choi, S.A.M. Abd El-Azeem, and Y.S. Ok. 2011. Effect of different seeding methods on green manure biomass, soil properties and rice yield in rice-based cropping systems. Afr. J. Biotechnol. 10:2024-2031.

Kaspar, T.C., D.B. Jaynes, T.B. Parkin, T.B. Moorman, and J.W. Singer. 2012. Effectiveness of oat and rye cover crops in reducing nitrate losses in drainage water. Agr. Water Mgt. 110:25-33.

Kearney, T., B. Marsh, S. Wright, and L. Jackson. 2006. Part 3. Seedbed preparation, sowing, and residue management, Small Grains Production Manual. University of California, Division of Agriculture and Natural Resources, CA.

Kiesselbach, T.A. and W.E. Lyness. 1934. Furrow versus surface planting winter wheat. Agron. J. 26:289-293.

Kirby, E.J.M. 1993. Effect of sowing depth on seedling emergence, growth and development in barley and wheat. Field Crops Res. 35:101-111.

Kristensen, L., J. Olsen, J. Weiner, H.W. Griepentrog, and M. Norremark. 2006. Describing the spatial pattern of crop plants with special reference to crop-weed competition studies. Field Crops Res. 96:207-215.

Larson, D.L., J.B. Bright, P. Drobney, J.L. Larson, N. Palaia, P.A. Rabie, S. Vacek, and D. Wells. 2011. Effects of planting method and seed mix richness on the early stages of tallgrass prairie restoration. Biol. Conserv. 144:3127-3139.

Loeppky, H., G.P. Lafond, and D.B. Fowler. 1989. Seeding depth in relation to plant development, winter survival, and yield of no-till winterwheat. Agron. J. 81:125-129.

Lueck, A.G., V.G. Sprague, and R.J. Garber. 1949. The effects of a companion crop and depth of planting on the establishment of smooth bromegrass, bromus inermis, leyss. Agron. J. 41:137-140.

Mahdi, L., C.J. Bell, and J. Ryan. 1998. Establishment and yield of wheat (Triticum turgidum L.) after early sowing at various depths in a semiarid Mediterranean environment. Field Crops Res. 58:187-196.

McLachlan, S.M., S.D. Murphy, M. Tollenaar, S.F. Weise, and C.J. Swanton. 1995. Light limitation of reproduction and variation in the allometric relationship between reproductive and vegetative biomass in Amaranthus-retroflexus (redroot pigweed). J. Appl. Ecol. 32:157-165.

Mohler, C.L. 2000. Enhancing the competitive ability of crops, p. 269-321. In: Leibman, M. C.L. Mohler, and C.P. Staver (eds.). Ecological management of agricultural weeds. Cambridge University, Cambridge, UK.

Mutz, J.L. and C.J. Scifres. 1975. Soil texture and planting depth influence buffel-grass emergence. J. Range Mgt. 28:222-224.

Olsen, J., L. Kristensen, J. Weiner, and H.W. Griepentrog. 2005. Increased density and spatial uniformity increase weed suppression by spring wheat. Weed Res. 45:316-321.

Olsen, J.M., H.W. Griepentrog, J. Nielsen, and J. Weiner. 2012. How important are crop spatial pattern and density for weed suppression by spring wheat? Weed Sci. 60:501-509.

Oxner, M.D., C.R. Dillon, T.C. Keisling, and P. Counce. 1997. An agronomic and economic evaluation of commonly used wheat planting methods in the lower Mississippi River Delta. J. Prod. Agr. 10:613-618.

Photiades, I. and A. Hadjichristodoulou. 1984 Sowing date, sowing depth, seed rate and row spacing of wheat and barley under dryland conditions. Field Crops Res. 9:151-162.

Popp, M.P., L.R. Oliver, C.R. Dillon, T.C. Keisling, and P.M. Manning. 2000. Evaluation of seedbed preparation, planting method, and herbicide alternatives for dryland soybean production. Agron. J. 92:1149-1155.

Redmann, R.E. and M.Q. Qi. 1992. Impacts of seeding depth on emergence and seedling structure in 8 perennial grasses. Can. J. Bot. Rev. Can. Bot. 70:133-139.

Regnier, E.E. and K.B. Bakelana. 1995. Crop planting pattern effects on early growth and canopy shape of cultivated and wild oats (Avena fatua). Weed Sci. 43:88-94.

Steinmaus, S.J. and R.F. Norris. 2002. Growth analysis and canopy architecture of velvetleaf grown under light conditions representative of irrigated Mediterranean-type agroecosystems. Weed Sci. 50:42-53.

Tadmor, N.H. and Y. Cohen. 1968. Root elongation in preemergence stage of Mediterranean grasses and legumes. Crop Sci. 8:416.

Tischler, C.R. and P.W. Voigt. 1983. Effects of planting depth on vegetative characteristics of 3 forage grasses at 14 days post emergence. Crop Sci. 23:481-484.

Van Horn, M., E.B. Brennan, O. Daugovish, and J. Mitchell. 2011. Cover crop management, p. 71-78. In: Smith, R.F., R.L. Bugg, O. Daugovish, M. Gaskell, and M. Van Horn (eds.). Cover cropping for vegetable production: A grower's handbook. Univ. of California, Oakland, CA.

Weiner, J., H.W. Griepentrog, and L. Kristensen. 2001. Suppression of weeds by spring wheat Triticum aestivum increases with crop density and spatial uniformity. J. Appl. Ecol. 38:784 790.

Yurkonis, K.A., B.J. Wilsey, K.A. Moloney, and A.G. van der Valk. 2010. The impact of seeding method on diversity and plant distribution in two restored grasslands. Restor. Ecol. 18:311321 . 